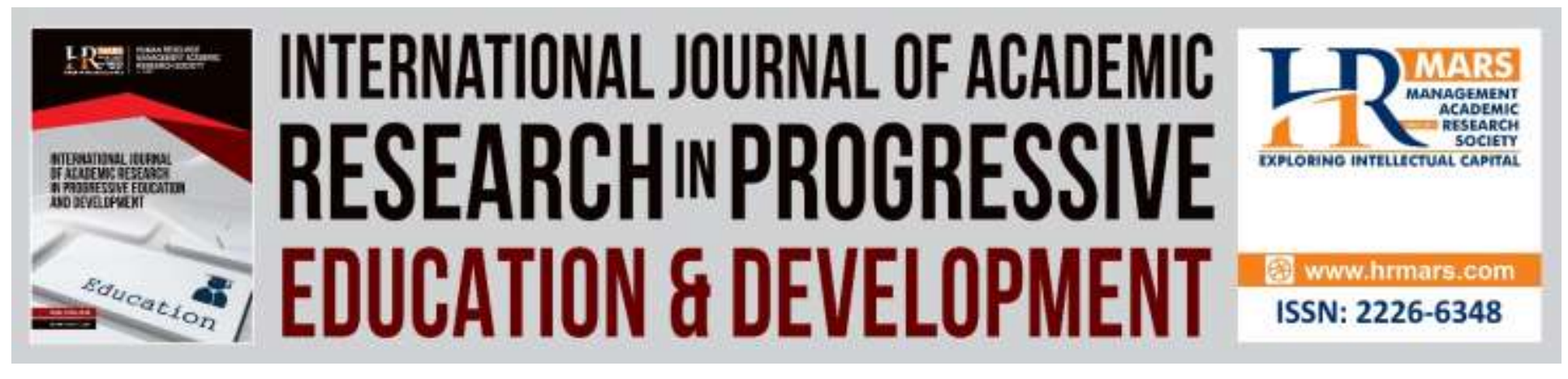

\title{
Setbacks vs. Recommendations: A Clearer Stance of the Officials of the Malaysia Prisons Department to Rehabilitate Child and Young Offenders within the Prisons Settings
}

\author{
Rosfizah Md. Taib
}

To Link this Article: http://dx.doi.org/10.6007/IJARPED/v8-i4/6907

DOI:10.6007/IJARPED/v8-i4/6907

Received: 19 October 2019, Revised: 30 November 2019, Accepted: 11 December 2019

Published Online: 30 December 2019

In-Text Citation: (Taib, 2019)

To Cite this Article: Taib, R. M. (2019). Setbacks vs. Recommendations: A Clearer Stance of the Officials of the Malaysia Prisons Department to Rehabilitate Child and Young Offenders within the Prisons Settings.

International Journal of Academic Research in Progressive Education and Development, 8(4), 1074-1087.

Copyright: (C) 2019 The Author(s)

Published by Human Resource Management Academic Research Society (www.hrmars.com)

This article is published under the Creative Commons Attribution (CC BY 4.0) license. Anyone may reproduce, distribute, translate and create derivative works of this article (for both commercial and non-commercial purposes), subject to full attribution to the original publication and authors. The full terms of this license may be seen

at: http://creativecommons.org/licences/by/4.0/legalcode

Vol. 8(4) 2019, Pg. 1074 - 1087

http://hrmars.com/index.php/pages/detail/IJARPED

JOURNAL HOMEPAGE

Full Terms \& Conditions of access and use can be found at http://hrmars.com/index.php/pages/detail/publication-ethics 


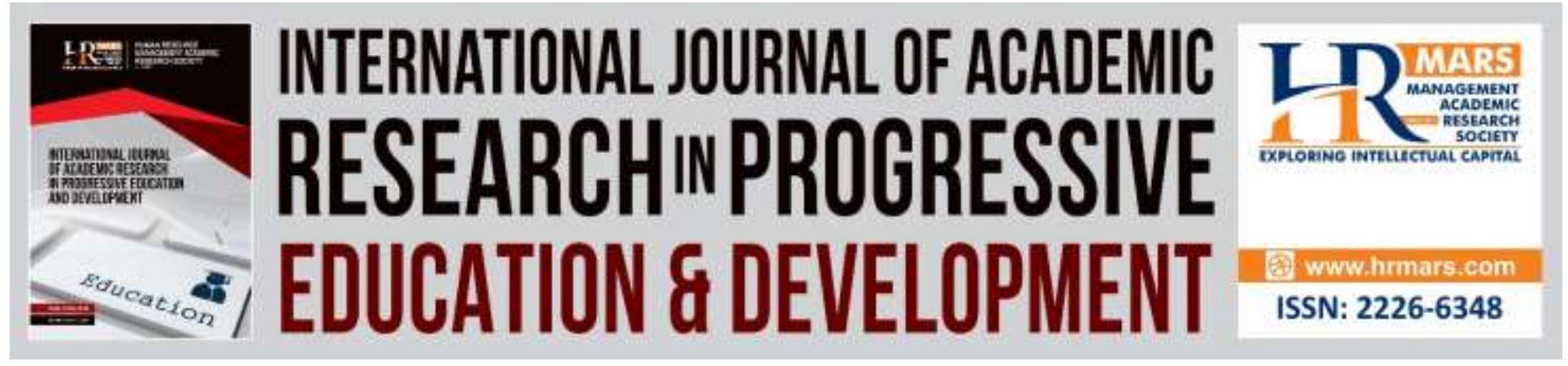

\title{
Setbacks vs. Recommendations: A Clearer Stance of the Officials of the Malaysia Prisons Department to Rehabilitate Child and Young Offenders within the Prisons Settings
}

\author{
Rosfizah Md. Taib, Ph.D \\ Faculty of Management and Economics, Universiti Pendidikan Sultan Idris, Malaysia \\ Email: rosfizah@fpe.upsi.edu.my
}

\begin{abstract}
This article aims to discuss findings from a recent study on how Malaysian prison officials understand the importance of education and its impact that will affect the entire policy of rehabilitating child and young offenders detained within the prisons settings in Malaysia. The study adopted a qualitative methodology approach applying face-to-face interviews with prison officials directly deal with matters related to rehabilitation programs for child and young offenders; looking for their views on the topic discussed. The data discover that, among others; first, the prison officials believe the provision of proper educational opportunities for child and young offenders throughout the imprisonment helps the entire process of transforming the youths become better persons and also after being released from the institutions; secondly, the element of education is always given priority by the Malaysian Prisons Department as an effective education rehabilitative approach aimed at restoring the confidence of the youths and helping them become more prepared to develop themselves before joining the community after the end of the imprisonment; and, several setbacks faced by the Malaysia Prisons Department when implementing policies related to the provision of education for youths pursuing learning activities whilst imprisoned have been identified; and the barriers can be well managed and resolved through a consistent understanding of the various Malaysian government departments pertaining to youth in Malaysia as well as the Prisons Department of Malaysia. In addition, efforts to reconnect the bond between the child/young offender-parent(s) need to be strengthened as positive impacts can keep the youths' momentum to survive as useful and persistent persons from returning to the criminal world.
\end{abstract}

Keywords: Child/Young Offenders/Prisoners, Rehabilitation, Education, Prison, Institutionalization, Malaysia 


\section{Introduction}

Discussion topics related to prisoner rehabilitation are usually linked to questions such as, the ability of prisoners to survive during imprisonment and after their imprisonment; and their ability to realize their past crimes. (Rosfizah, 2012; Benard \& Felicia, 2015). Efforts undertaken by the Malaysia Prisons Department to lead prisoners to return to society through the implementation of various systematic and organized rehabilitation programmes - which are closely linked to this article lies on the "Putra Module", primarily designed to integrate various rehabilitation programs for child and young offenders to be changed persons after released from the prisons institutions. (Rosfizah, 2011; 2012; 2013; 2014).

To date, the Malaysia Prisons Department has been referring to the "Putra Module" - the blue print for the department sought to direct the department to consistently integrate various education programs/modules/activities within the rehabilitation process driving young offenders stop having criminal minds and/or negative behaviour during incarceration and ultimately after released from the institutions ${ }^{1}$.

Currently, there are 12 'schools within prisons' or also recognized as "Integrity Schools" across the country which were established on the zone basis: Kajang Integrity School (Central zone), Kluang Integrity School; Muar Integrity School (Southern zone), Marang Integrity School (Eastern zone), Sungai Petani Integrity School (Northern zone), Bentong Integrity School (Eastern zone), Kota Kinabalu Integrity School, Kuching Integrity School (Sarawak), Puncak Borneo Integrity School other than the Malacca Henry Gurney School and Keningau Henry Gurney School ${ }^{2}$.

Henceforth, the paper provides a discussion that would explain how prison officials of the Malaysian Prisons Department shed the stand whilst carrying out their duties towards rehabilitating child and young offenders detained within the prisons institutions. Furthermore, the article will extend the explanation on views of the officials regarding some recommendations in response to the setbacks they faced to stimulate the implementation of relevant policies.

The data cover the findings from the interviews with three respondents involved directly in the management of the rehabilitation process of child and young offenders within the Malaysian prisons institutions.

Subsequently, the following research questions have been addressed in the present article; namely:

\footnotetext{
1 Basically, the module consists 4 phases, namely "Disciplinary Building Programmes" (Phase 1), "Moral/Attitudes Reinforcement Programmes" (Phase 2), "Skills Programmes" (Phase 3) and "Humanity Programmes" (Phase 4). Refer details in MT Rosfizah (2011); Educating and Rehabilitating the Child and Young Offenders in the Prisons: A Practice in Malaysia; ICYouth 2011; 1-3 November 2011

2 Read further Rosfizah Md. Taib, Educating and Rehabilitating the Child and Young Offenders in the Prisons: A Practice in Malaysia, ICYouth 2011, Palm Garden Hotel, Putrajaya, Malaysia; 1-3 November 2011 and the website of the Malaysia Prisons Department: www.prison.gov.my
} 
Vol. 8, No. 4, 2019, E-ISSN: $2226-6348$ @ 2019 HRMARS

(i) How do prison officials of the Malaysian Prisons Department express their thoughts and beliefs about the importance of education towards strengthening the entire process of rehabilitation of child and young offenders in Malaysian prisons?; and,

(ii) To what extent the Malaysian Prisons Department may offer measures to strengthen the implementation of educational opportunities towards strengthening the entire rehabilitation process of child and young offenders in Malaysian prisons?

Therefore, the research objectives set in the current article are:

(i) To examine the thoughts and beliefs of the Malaysian prison officials on how they confide that education is important towards strengthening the entire process of rehabilitation of child and young offenders in Malaysian prisons; and,

(ii) To observe the feelings and reflections of the Malaysian prison officials towards offering measures to strengthen the implementation of educational opportunities towards strengthening the entire rehabilitation process of child and young offenders in Malaysian prisons.

The purpose of this article is to discuss whether the stance and insights of the Malaysian prison officials on the topic will shed lights on better assist the reinforcement of policies related to the entire rehabilitation process of child and young offenders through education within the Malaysian prisons settings.

\section{Literature Review}

Originally, in 2008, the Malaysia Prisons Department started off to formally implement the formal education program or 'schools within prisons' for child and young offenders detained within the prisons settings like normal schools outside the institutions, called "Integrity Schools", which in turn, the policy has been upgraded from year to year now. (MT Rosfizah; 2011; 2013; 2014; 2018). The policy that initially meant to decay the illiterate issues among child and young offenders through reading, computing and writing activities has raised a vast interest among the youths to develop them during the imprisonment.

Many academic achievements recorded by young offenders pursuing studies whilst imprisoned have encouraged the attention of the Malaysia Prisons Department to strengthen their rehabilitation program through various educational programs from time to time. (Utusan Malaysia, 2015; Harian, 2015; Nayan, Mahat, Hashim, Saleh, \& Norkhaidi, 2018).

Several success academic stories notably by Malaysian young offenders in public examinations include among others; in 2017, 13 students obtained 4A to 9A in 2017 Sijil Pelajaran Malaysia; three students from 157 candidates got 7A and at least 68 people got $1 \mathrm{~A}$ in 2016 Sijil Pelajaran Malaysia (Metro, 2017; Malaysia, 2017) and one student of Sungai Petani Integrity School got 7A and 1B in SPM 2010 (Malaysiakini, 2012; Zulfadhli, 2018).

Sandra J. Bell (2017) opined that educational programming is an important part of correctional programming as many young offenders have experienced failure in their previous schools prior to the admission of the detention centre.

In undertaking their duties providing various formal and informal approaches while dealing with children and young people placed in institutions, professional practitioners/trainees intend to build up positive relationships with the youths in that this will encourage participation in the learning environment (Turner, 2014). 
Young delinquents are more likely to relate to their academic needs and general interests as well as just to fill their leisure while in prison. Participants in the study presume the opportunity to pursue knowledge from primary to secondary school and higher education during the detention period helps them to think critically and logically about their future (Rafedzi \& Abrizah, 2016). Tewksbury and Dabney (2009) remarked that those who work within the system; for instance, the prisons institutions have different views than those represented by politicians and support programs, services, and resources to meet inmates' multitude of needs while normalising the environment. The view that imprisonment can prevent children from continuing to engage in crime after the imprisonment period ends is always contradicted with the argument that there are still studies proving otherwise (Samuri \& Awal, 2015).

\section{Methodology}

The present paper endeavours to reveal some findings extracted from a recent study conducted in the Malaysia Prisons Department regarding the implementation of the rehabilitation process of child and young offenders through education within the Malaysian prisons institutions.

The interview data with prison officials discussing about the prison officials' experiences; thoughts and beliefs about the topic are presented towards answering the predetermined Research Questions as mentioned earlier.

Three respondents were selected based on a purposive sampling where the researcher attempted to explore the attitudes and mindsets of the prison officials who served significant roles with the management of child and young offenders placed within the prisons institutions in Malaysia.

Prior to the interviews, arrangements were made with the Head Quarters of the Malaysia Prisons Department, finding the time and schedule appropriately to conduct the face-to-face interviews with the individual respondent at a time.

Realistically, the date of all interviews has been revised quite several times as respondents have tight schedules and various ad-hoc routines. In conducting qualitative investigations, the researchers can anticipate that such a situation will easily occur understanding the respondents are high-ranking officers in their departmental management line-ups. Although it was sometimes difficult to expect, however, the researchers were more than appreciative of the willingness and readiness of all respondents to be interviewed and these feelings ultimately overcome all the difficulties that need to be addressed in the early stage of the study.

For the purpose of the discussion in this paper, the respondents are given pseudonyms as follows: "Nazam"; "Dayang" and "Tahir" in which these identities are not referring to their real names and/or positions held. In this respect, their original names and positions are hidden to maintaining their identification in order to preserve the ethical issues of research requirements. However, their actual identification is only known to the researchers.

All the interviews were based on a set of semi structured questions that acts as a guide to both the researchers and the respondents. Interview questions were sent to the respondents before the interview dates which this allowed them to get an idea of what the researchers meant to explore in the study as well as to encourage them to be more prepared to provide feedback during the interviews. Finally, the respondents were observed to have acted independently and were not prejudice when expressing their opinions and views upon the questions posed. 
The entire interview process took place without compulsion and both the researchers and respondents gave appropriate space and opportunity to one another accordingly, so that new and/or emerged issues or questions arising out of the interview guide will be responded by the participants in particular regarding the topic of the study. Later, the data analysis process was transcribed manually according to the emerged codes and labels towards answering the research questions as mentioned earlier.

Finally, the findings of this study will be used to identify the extent to which the prison officials of the Malaysia Prisons Department are aware of the impact of education programs implemented on child and young offenders in Malaysian prisons are able to assist the whole rehabilitation process within the target group of the offenders within the Malaysian prisons system.

\section{Findings and Discussion \\ The Importance of Education}

Ultimately, the prison officials see education as the fundamental tool designed to rehabilitate child and young offenders to be better persons during incarceration. They believe that education operates as the right tool, in a more accurate sense, can change the previous criminal minds in youth towards becoming useful citizens after being released from the institutions later.

For instance, Dayang expressed: “...[w]hen we look at the concept of education, when you open the school door, you will close the prison's door!... Someone has quoted it. I agree with that quotation because of the young prisoners who have (obtained) education in prisons, and have been released, we do not see them coming back. That is the (effective) tool......"

Another prison official, Nazam emphasized; "I think this (education) is the most appropriate step in improving academic standards among Malaysians. We should not downgrade those (child and young offenders) because the education opportunity is for everyone! At least, let's not downgrade them personally, for whatever mistakes (they had committed). So we should get them back (rehabilitate them) .... So at least, if they get the benefits for them and their families (education) ... with the certificates they have, they will not be able to rethink (about) criminal activities (anymore). That is the opportunity that Malaysians need. If they go out of prisons without knowledge and academics, they are still at a disastrous level..."

By encouraging child and young offenders changing their previous criminal mindsets, indirectly, this would train them to be criminal free persons once released from the institutions. We may capture the thinking of the Malaysian Prisons Department officials that they predicted, by providing adequate education programs to child and young offenders during imprisonment, this will help the department to achieve their mission towards providing an effective rehabilitation process to these young ex-wrongdoers.

In addition, the prison officials explicate that, taking into account education as their paramount concern when managing child and young offenders within the prisons settings, they actually help the child and young offenders to begin to respect themselves that they are still useful people who can contribute not only to themselves but to their families and the society in general.

Tahir elucidated; "What I see, we must put our focus on what has been accounted for.... my mindset should be focused (seeing the prisons institutions) as a school that I need to lead rather than a prison because it is a different setting. I am here (acting) as a father who cares for children under 21 years old. When focusing on it, (my) mindset and mentality need to be corrected. I 
consider them not as liabilities but as assets. If we think this, then we are in that direction. They are not burdens; they are the assets that need to be guided to become dignified teens that have a sense of identity. We build them so they return to society as productive teens who can later make themselves, families and society to be proud off!"

Likewise, Nazam added; "In prisons, we are more to (cure), prevention so they (child and young offenders) do not repeat their crimes. That's why we hold programs in prisons (similar) to programs in schools; the academics are part of the rehabilitation (modules)..."

In this regard, we may understand that the Malaysian prison officials assume that the rehabilitation process of child and young offenders through adopting education could also strengthen the overall rehabilitation process of child and young offenders placed within the Malaysian prisons institutions.

Meanwhile, Dayang recounted; “... So, education has done some good to them, (contributes) benefits (to) the prisoner themselves. To the department (the Malaysian Prisons Department), we feel that our vision is to create excellent people through effective rehabilitation (process). It is effective that we see why we make (educational) programs that fit the lives of people outside, and we do not see them come back (inside). When people are not coming back (return to prisons), we are talking about the costs of prison, the prison's image, and of course, for family these (rehabilitated offenders) are (still) assets, we change liabilities to assets. Once (during the early stage of rehabilitation), it's a challenge because of their previous (bad) minds. But with the right approach, if put them in the right place with the right approach... so we have also done justice to them and the department and the country; we have (managed) to rehabilitate the child and young offenders sent to us (prisons) to be rehabilitated ..."

In addition, the prison officials were firm in pointing out their stand and their spirit to prove that academic and vocational programs are their most preferred programs that can be used as an appropriate channel to help children and youth offenders become more conscious and transformed persons. Quoted from Tahir: "... here (within prisons institutions), we want to make academic as our core treatment! We also want to make (prisons institutions) as a vocational school with all approaches (learning activities) and certification programs (accredited)..."

To this far, we apprehend that the Malaysian Prisons Department is objective in putting forward their mindsets of believing that education is inevitably a right to be fulfilled to child and young offenders and therefore, they will persistently fulfilling their duties accordingly.

\section{Measures and Recommendations}

When discussing about their motivation towards changing previous young criminals to be better persons while being imprisoned, the prison officials shared some of their viable perspectives. Useful points to be noted under this sub-heading are as the following:

i. Get Continuous Support from the Government and Various Governmental Agencies/Departments

First and foremost, the researchers discovered that the Malaysian prison officials realized that the key factor in tackling the current issue would begin with how the Malaysia Prisons Department would gain a solid support from the government of Malaysia, particularly in supplying sufficient learning facilities and materials proportioned to those child and young offenders pursuing studies within the prisons settings. 
For example, Tahir commented; “.... (Actually), (e)ducation is worth to be paying attention for... in the present education system, the education (implemented for child and young offenders) is not processed in a professional way. (It is true) the prisons department is under our control, but why not there is another body (organization) sitting together (co-operate with the Malaysia Prisons Department), like the university (which) has a (special) Dean (a proper and systematic and organized institution acting as a leader/manager) who organized the school and we were all there? It may be possible to appoint a person who plans... to function as a middleman; program leader...."

Although the suggestion seems quite extreme as if the Malaysian Prisons Department requested a unit or division under the Ministry of Education to be specifically set up to deal with education management for CYO placed within the prisons settings; however, this idea highlights that what is actually happening in the present system appears to be less organized and manageable.

Added by Nazam, asserting the similar issue: “... Our constraints... Human resource... equipments and financial! Those are our constraints ... like staffing (the human resource aspect). (Currently), many (new prisons) institutions (being) opened, so meaning, staffing (matters) is relevant, right? ... our (financial) allocations (educational needs) (to be) given (to CYO) depending on (our) financial abilities, the money to buy equipments, stationeries like notebooks, pencils...."

Based on the above excerpts, it is quite clear that the critical part that must be addressed by the Malaysian government is directly related to infrastructural and learning facilities that are still inadequate in order to meet the necessities of children and young persons who are pursuing education within the Malaysian prisons institutions.

To overcome the issue, what is being practiced is that the Malaysia Prisons Department has done what is to be done adjusting and modifying the prisons settings transformed to classes enabling those young learners in the prisons to get a proper education.

Dayang unveiled, "... (i)n terms of facilities available in prison. Basically, prisons are not built for school, so we're changing the available space for school. (But) our school (prison-designed) ... if in terms of comfort, (that's not) may be... learning materials and all are (still) very minimal..."

Further stressed by Tahir; "... (to) make this all (educational provisions for child and young offenders) successful, the infrastructure plays a major role. We (the Malaysia Prisons Department alone) cannot afford it! ... morning (sessions) (the very same building is being utilized for the academic programs), if there are other buildings that are more than that, many children will sit for SPM and (more and more) teachers can be sent (into the institutions) ... why not to focus on improving the rehabilitation of facilities and infrastructure so (education plan in prisons institutions) (could) be more perfect and successful?"

Along the way, Nazam still hopes the Government will continue to be confident of the Malaysia Prisons Department's ability to revive the child and young offenders through a range of education programs by continuously supplying various learning facilities to prisons institutions for the benefits of the youth pursuing studies inside the institutions; ".... hope the government will provide infrastructure to be more organized and systematic for child and young prisoners so that they can pursue academic programs (more fully) whether academically or theoretically. We (the Government) can (in fact) provide a more complete facility simply as (available) in schools (outside the institutions), (with suitable) computer facilities... more comfortable classes, and (with) the (more serious) involvement of the Ministry of Education... meaning, in terms of teacher 
provisions ... (more) suitable and (more) competent teachers (sent into the institutions). We are not requesting more! If it can be (just) the same (as outside schools), if we want to do some kind of skills, it can be the same as what they do outside (outside the prisons institutions). Like a vocational college ... (as if) we (could always) make a special (too) in prisons institutions."

In an extensive explanation, Tahir explained; "Therefore, we need the support and assistance of all parties. At present, all (many) are busy (many other government departments) come here (to prisons institutions) (to contribute in various forms of cooperation) .... schools (within prisons settings) only a few; (if) the Ministry of Education (can come here), they can assist in the provision of (facilities) classes for schools, then, JAKIM (and any agency related to religious matters) (may come here). ... to assist (provide more) (educational)... adequate supply (of teachers) is (just) perfect. Things to be contributed (are) not (that) much, (finally), the system (the provision of educational programs within the prisons institutions) will become even stronger!"

\section{ii. Openness to Welcome Collaborations from outside the Institutions.}

From another perspective, the prison officials opened their minds more widely towards welcoming any sort of relevant collaboration from outside the institutions simply to intensify practical and effective implementation of the education programs for youth offenders placed within the institutions.

Tahir elaborated in a firm tone: "We cannot maintain the 'closed doors' (policy) any longer. Serious (attention and action) should be given by certain agencies, (these all) are not the only prison's (Malaysia Prisons Department) duty (alone)! .... because we cannot move in silo, alhamdulillah (thank God), I see the vast opportunities with JAIM and MAIM (Religious Departments), then, with UTEM (and) all, because we have no expertise, so we need them (other agencies) to come (cooperate with prisons institutions)."

Nazam reemphasized the same point: "...(w)e are still silos, that is the barrier we have to solve! The school was supposed to be (just) anywhere... in prisons (for example); still (needs to have) schools.... this is why many outside companies (inspired to offer) CSR (Corporate Social Responsibility activities). We make CSRs with (quite several) departments (outside of prisons institutions). Like Microsoft... they provide a laboratory (computer) at the Henry Gurney ('schools within prisons institutions' in Malacca). We (also) have a partnership with Metro... (offers) driving (ethical courses)..."

In due manner, we capture the thoughts of prison officials that the perception that we usually understand is the duty to maintain the obligation to correct the behavior of the prisoners is not only borne by the Prisons Department of Malaysia alone.

Apparently, we may feel the prison officials are humble to admit how lack they are in other respective areas and useful fields other than providing a safe and secure place for the child and young offenders within the institutions. In this point of view, we find encouragement among prison officials to stimulate the implementation of educational opportunities towards strengthening the overall rehabilitation process of children and young offenders in Malaysian prisons should not be taken lightly. Henceforth, it seems that they are getting ready to be more open to welcoming any outside agencies who voluntarily want to devote to the child and young offenders in prisons with the intention solely to help the Malaysia Prisons Department to seeing 
child and young offenders becoming useful persons in the near future or at least upon their release.

Dayang was also in the same wavelength; “... (b)ecause (to date), we (managed) get cooperation (with outsiders)... in sports (one example) with the National Sports Council... culture and arts with their respective cultural departments where they send instructors (into the prisons institutions) like (teach CYO) (skills) singing, theater dance (various arts and culture skills) to groom them (CYO) into this field and give them (CYO) certificates, and (consequently), they (CYO) are offered to become coaches in this field. Now, we see we stretched out education (programs) into several (other) branches - academic, sports, skills, culture and arts."

Tahir supported the same policy: “...(m)yself (especially), encourage NGOs to come, (if) before, they came to (simply) visit only, I do not want (this approach) to be that (way forever) because we are not a Zoo.... Come here, let's get the 'win-win' (situation), they (outside agencies) can make (any) programs, I ask them to bring motivators (for example).... (there is one agency) They brought blind people to come here to play music (a charity show to child and young offenders). In addition, (there are agencies) NGO (adopt) approaches such as more specialized (in) treatment and approach rehabilitation (activities)... (this is the kind that) we are very much welcome!" Dayang too, commented: “... (b)ecause (todate), we (managed) get cooperation (with outsiders)... in sports (one example) with the National Sports Council... culture and arts with their respective cultural departments where they send instructors (into the prisons institutions) like (teach child and young offenders) (skills) singing, theater dance (various arts and culture skills) to groom them (child and young offenders) into this field and give them (child and young offenders) certificates, and (consequently), they (child and young offenders) are offered to become coaches in this field. Now, we see we stretched out education (programs) into several (other) branches academic, sports, skills, culture and arts."

Strengthen a Policy Related to "Parent(s) - Child/Young Offender Relationships"

When moving forward to realize efforts related to the rehabilitation of child and young offenders through education, the institution is aware that another important element to be considered is to strengthen the policies relating to "parent(s) - child/young offenders relationships". The officials recognized that even these child and young offenders are presently living behind bars; still the bond with their parents should not be kept distantly.

Aware of the significant of the policy, Tahir shared one of his experiences; "In terms of virtue, parents who come to the institution by bus far away from Kota Bahru (for example), we provide shelter for them. The place (the visit area) is also upgraded to be conducive (enough) - a 'close visit' (for parent(s)-child). (The) family relationship is very important. To those (children and young offenders) who are (up to) 3-4 months are not contacting to each other (parent-child), so, we (the management) will inquire (children and young offenders) (and later, take the initiative) ask if they have money to make a call request. Or if (the child and young offenders) have no money, we (the management) will give them (a chance to) contact their parents once a month ... we (also) will track which (child and young offenders) (who) have never been able to meet up (their parents)... There are some (child and young offenders) who have been arrested (escaped from the institution), then, (the management) asked why they ran away; (they answered) because they missed (their) father, family...only (now), (they) just remembered (the parents)!..." 
The reality of being imprisoned is, in a layman's language; already a torture! This is where the Malaysia Prisons Department has to play their prudent part to reunite the partially broken relationship between the parent(s) and the child/young offenders.

Nazam frankly spoke: "In fact, the family plays an important role in prisons. They (family members) must give support from outside (prisons), they (family members-prisoners) should meet up, (family members) should come to advice their children, so those children can behave themselves (realize to change)..."

We can see how the most relevant policy is to make a tremendous impression on child and young offenders towards reviving self-confidence among them. The strong impact of the family still affects the entire development of offenders even though they live separately.

Dayang reconfirmed: "...Especially those who are with the academic program, before they sit for the SPM ("Malaysia Higher Certificate"), we have a "Restu IImu" Program ("Blessing Day"). We will call the parents to make prayers like regular schools (outside the institutions), we will do somewhere around September. (During) the whole day, we will assign a counselor (to stay) with the family, they will discuss the performance of these children ... we ask the parents (they) to pray for their children (approaching the exam day), we make prayers... we do a lot of stuff together (as a parent/family program) as it is a one day program for the family to be together with their children."

\section{Conclusion}

This paper has sought to answer the research questions designed earlier intending to reveal how the perceptions and actions of the Malaysian prison officials manage matters related to educational provisions among child and young offenders in Malaysia affect the implication of the relevant policy discussed.

In summary, the above mentioned points may be reflected as the following:

First; the Malaysian prison officials are clear in their minds and actions that their principal roles are to enhance the Malaysian government policies pertaining to providing a proper education to child and youths pursuing studies whilst imprisoned. This is consistent with the Malaysia Prisons Department's mission and vision, being the correctional agency for the country that is to provide effective rehabilitation programs other than to provide a secure place of detention to prisoners; Next; the Malaysian prison officials seem to understand that education is influential to stimulate child and young offenders change in their behavior and actions become useful persons during the term of imprisonment and also after being released from the institutions later;

We may also denote that, in due course, the implementation of education programs among child and young offenders within the Malaysian prison settings may also help the youths to clear up their negative and criminal mindsets during the imprisonment as well as this, in gradual, will train them not to repeat the same mistakes committed in the past;

Meanwhile, the Malaysian prison officials are also aware of some issues and obstacles that must be addressed to ensure the overall implementation of policies relating to the rehabilitation of child and young offenders through education can run smoothly and successfully, among others, involving issues like the lack of proper educational facilities and materials; the needs of the Malaysia Prisons Department urging for suitable collaborations with various governmental 
department and stakeholders outside the prisons institutions; as well as to recreate, reconnect and rebuild half ruined relationships of "parent(s) - child/young offenders";

From the findings also, it is also worth noting that all those identified challenges are foreseen as manageable provided the Malaysia Prisons Department can get a firm and solid support from the relevant governmental agencies; for example, the Ministry of Education, the Ministry of Youth and Sports, Ministry of Home Affairs, State Religious Departments and many other related agencies directly or indirectly dealing with maintaining the interests and rights of young prisoners in the country;

Apart from that, we also may apprehend that as administrators and policy makers representing the Malaysia Prisons Department, the prison officials are always looking forward to the best approach to succeed in a planned rehabilitation program to maintain the best interests of the youth offenders to be upheld at all times during the imprisonment.

Finally, the article concludes that the implementation of policies relating to the safeguarding of the opportunity for child and young offenders pursuing studies within the detention period can be restored if the Malaysia Prisons Department's top management gets unwavering support from the government in particular towards producing a new generation that can contribute more to the wellbeing of the country completely.

\section{Acknowledgement}

This paper is based on the research project entitled The Development of Educational Opportunities for Child and Young Offenders within the Malaysian Prisons Institutions since 2013. The authors would like to extend their gratitude to the Research Management and Innovation Centre (RMIC), Sultan Idris Education University (UPSI) for the University Research Grants (code: 2018-0072-106-01) that helped fund the research.

\section{Corresponding Authors}

Rafiduraida binti Abdul Rahman, PhD

Email: rafidurraida@fpe.upsi.edu.my

\section{References}

Ashkar, P. J., \& Kenny, D. T. (2009) Young Offenders' Perceptions of School: An Ecological Analysis, Psychiatry, Psychology and Law, 16:3, 355-368, DOI: 10.1080/13218710902930283

Bain, A., and Parkinson, G. (2010), Resettlement and Social Rehabilitation: Are We Supporting Success? The Journal of Community and Criminal Justice, 2010, Vol 57(1): 63-74, DOI: $10.1177 / 0264550509354669$

Barry, M. (2010), Youth Transitions: from Offending to Desistance, Journal of Youth Studies, Vol. 13, No. 1, February 2010, $121-136$.

Benard, K., \& Felicia, Y. (2015). The Role of Visual Semiotics in Shaping Hiv and Aids Discourses in Kenyan Print Media: A Case Study of A Newspaper Advertisement. Multilingual Academic Journal of Education and Social Sciences, 3(1), 1-16.

Budin, D. (2014), Pendidikan Juvana di Jabatan Penjara Malaysia: Dasar, Hala Tuju, Pelaksanaan dan Cabaran, Jurnal Hadhari 6 (1) (2014) 87-104 
Carrigan, J., \& Maunsell, C. (2014) 'Never really had a good education you know, until I came in here': educational life histories of young adult male prisoner learners, Irish Educational Studies, 33:4, 399-417, DOI: 10.1080/03323315.2014.977642

Jennifer, S. (2017), Children in Trouble with the Law and the United Nations Convention on the Rights of the Child; http://eserv.uum.edu.my/docview/1964384635?accountid=42599; Illinois State University, ProQuest Dissertations Publishing, 10284881

Kennedy, A. (2013) Education in custody: young males' perspectives, Contemporary Social Science, 8:2, 104-119, DOI: 10.1080/21582041.2013.767467

Rosfizah, M. T. (2018); The Institutional Experience and Lessons Learned By Young Offenders in a Malaysian Prison; International Journal of Business, Economics and Law, Vol. 17, Issue 2 (December) ISSN 2289-1552; 43-50

Educating and Rehabilitating the Child and Young Offenders in the Prisons: A Practice in Malaysia; Papers presented at The ICYouth 2011; 1-3 November 2011

Rosfizah, M. T. (2012); Educational opportunities for Malaysian child and young offenders: realizing children's rights or rehabilitating offenders; a PhD Thesis; EThOS ID: uk.bl.ethos.582888; retrieved:

https://ethos.bl.uk/OrderDetails.do?uin=uk.bl.ethos.582888

Rosfizah, M. T. (2013); Attitudes of Educators and/or the Management Staff of Integrity Schools within the Prisons Institutions in Malaysia. Papers presented at The IMEC 2013; Ipoh, Perak, Malaysia. 1-3 November 2011

Rosfizah, M. T. (2014). The Influence of Children's Rights in the Implementation of the Provision of Education for Young Prisoners in Malaysia; Papers presented at The International Conference on Law, Policy and Social Justice (ICLAPS 2014). Penang, Malaysia. 10-11 September 2014

Rosfizah, M. T. (2014). Educating Malaysian Young Prisoners towards Becoming Useful Citizens. Papers presented at The INSAN 2014. UTHM, Malaysia. 9-10 April 2014

Rosfizah, M. T. (2014). The Influence on Policy and Practice of Particular Notions of Rehabilitation of Offender within the Malaysian Prison Institutions. Papers presented at The ISDC 2014. Langkawi Island, Malaysia. 12 -13 August 2014

Rafedzi, E. R. K., \& Abrizah, A. (2016), Information needs of male juvenile delinquents: the needs to be met in a prison setting; Volume: 32 issue: 3, page(s): 592-607; Article first published online: December 15, 2014; Issue published: June 1, 2016; https://doi.org/10.1177/0266666914563357

Sandra, J. B. (2017). Young Offenders and Youth Justice. A Century after the Fact. Nelson Education. Toronto, USA.

Smeets, E. (2014) Education in young offender institutions and secure youth care institutions, Educational Research and Evaluation, 20:1, 67-80, DOI: 10.1080/13803611.2013.872040

Sutton, J., \& Austin, Z. (2015). Qualitative Research: Data Collection, Analysis, and Management. The Canadian Journal of Hospital Pharmacy, 68(3), 226-231.

Teh, Y. K. (2008). Female Prisoners in Malaysia, Journal of Offender Rehabilitation. 43:1, 4564. DOI: 10.1300/J076v43n01_03 
Turner, Debrah. (2014). Parents, Carers and the Community: the Collaborative Relationship. 177192. Routledge Taylor \& Francis Group. London and New York

Tewksbury, R., and Mustaine, E. E. (2009). Insiders' Views of Prison Amenities: Beliefs and Perceptions of Correctional Staff Members in Tewksbury, R and Dabney, D (2009). Prisons and Jails. (Ed.) (2009). McGraw Hill.

Nayan, N., Mahat, H., Hashim, M., Saleh, Y., \& Norkhaidi, S. B. (2018). Verification of the Instrument of Climate Literacy Knowledge among Future Teachers: Confirmatory Factor Analysis (CFA). International Journal of Academic Research in Progressive Education and Development, 7(3), 26-39.

Zulfadhli (2018). Determination of Industrial Competitiveness on Manufacturing Industry Growth in Palembang City, International Journal of Academic Research in Accounting, Finance and Management Sciences 8 (3): 238-254.

\section{Online Newspaper Articles}

No author (2017). 18 juvenil Sekolah Integriti Penjara Kajang Cemerlang SPM 2016. Utusan Malaysia. Retrieved from Utusan Malaysia Online

Zulkifli, N. (2016). Penghuni Henry Gurney Tekad Berubah. Utusan Malaysia. Retrieved from Utusan Malaysia Online

Hamat, S. (2017). Kami Kembali Bangkit. Retrieved from Harian Metro Online

No author (2017). Pelajar Sekolah Henry Gurney diharap dapat menguasai latihan dipelajari. Utusan Borneo. Retrieved from Utusan Borneo Online 